\title{
Resolving Legitimacy Deficits in Technology Startups through Professional Services Practices \\ Jay Payette
}

\author{
"You can't build a reputation on what you are going to do." \\ Henry Ford (1863-1947) \\ Business magnate and founder of Ford Motor Company
}

\begin{abstract}
As new ventures, technology startups face a key challenge that is specifically associated with their young age: a perceived lack of organizational legitimacy. Organizational legitimacy is an important factor in the growth and survival of new ventures and is therefore an important issue for managers and entrepreneurs to address. Although there are many different typologies for defining types of organizational legitimacy, this article argues that technology startups should focus on developing external pragmatic legitimacy as a means of acquiring the resources required to grow and thrive. However, despite the many ways by which an organization can develop external pragmatic legitimacy, few are well suited to technology startups. Based on a review of the different types of organizational legitimacy and an assessment of their applicability to the context of technology startups, this article recommends that technology entrepreneurs should consider the creation of professional services practices to help develop external pragmatic legitimacy and overcome the "liability of newness".
\end{abstract}

\section{Introduction}

New ventures face challenges specifically associated with their organizational age, such as a lack of management structure and specialized role definition, a small or non-existent customer base, and a considerable dependence on the decision making and performance of the founder(s) (Stinchcombe, 1965; Freeman et al., 1983; Chrisman et al., 1998). One of the dimensions of this "liability of newness" is a perceived lack of legitimacy (Freeman et al., 1983; Singh et al., 1986). Although there has been a considerable amount of research conducted in the field of organizational legitimacy over the past three decades (e.g., Singh et al. 1986; Suchman 1995; Deephouse \& Carter, 2005; Diez-Martin et al. 2013), these efforts have produced precious few specific recommendations of how new ventures - particularly technology startups - can create, or develop, legitimacy. Without specific approaches to developing organizational legitimacy, entrepreneurs are left to improvise legitimacy-building tactics on their own, that is, assuming that they recognize that others may not perceive their young company as legitimate. This article outlines an implementable approach that technology startups can use to build legitimacy: building a professional services practice. This approach is proposed as an attractive method for technology startups to develop external pragmatic legitimacy, which is identified as an ideal form of legitimacy for new ventures to pursue based on an analysis of the existing literature.

The article is organized in three main sections. First, the relevant literature is reviewed to highlight the various forms of legitimacy and to explain why developing external pragmatic legitimacy was selected as the objective of the proposed solution, as opposed to developing other types of legitimacy. Second, the solution section, which represents the main contribution of this article, recommends that entrepreneurs build a professional services practice as an attractive approach to resolving the deficit of legitimacy faced by technology startups. Finally, the conclusion summarizes the findings and recommends further avenues of research. 


\section{Resolving Legitimacy Deficits in Technology Startups through Professional Services}

Jay Payette

\section{Why Legitimacy Is Important to Technology Startups}

Legitimacy contributes to a firm's ability to acquire the resources it needs to grow (Zimmerman \& Zeitz, 2002; Tornikoski \& Newbert, 2005; Nagy et al., 2012; DiezMartin et al., 2013). These legitimacy-dependent resources are particularly important for the growth and survival of new ventures (Starr \& MacMillan, 1990; Hunt \& Aldrich, 1996). The importance of legitimacy for the survival of new ventures can be partially attributed to the reluctance of others to engage in commercial relationships with organizations they deem unlikely to survive (Zimmerman \& Zeitz, 2002; Tornikoski \& Newbert, 2005).

There have been several efforts over the past decades to both define and construct a typology around organizational legitimacy (e.g., Deephouse \& Carter, 2005; Reuf \& Scott, 1998; Scott \& Meyer, 1991; Aldrich \& Foil, 1994). However, notable among the collection of research efforts that have made contributions to the study of organizational legitimacy is Mark Suchman's (1995) seminal paper "Managing Legitimacy: Strategic and Institutional Approaches". Suchman's definition and topology are used in this article given the considerable degree to which Suchman's work has been referenced and built-upon by subsequent research efforts.
Suchman (1995) defines organizational legitimacy as "a generalized perception or assumption that the actions of an entity are desirable, proper, or appropriate within some socially constructed system of norms, values, beliefs, and definitions". The key to this definition is the implied roles of two entities: i) an entity who is evaluating the legitimacy of an organization, and ii) the organization whose legitimacy is being evaluated.

Although Suchman's definition of legitimacy is somewhat generalized, he also constructs a typology defining three categories of organizational legitimacy: pragmatic legitimacy, moral legitimacy, and cognitive legitimacy (Table 1). These three types of legitimacy are distinguished by defining interpretations of legitimacy via three different behavioural dynamics. Although the three types of legitimacy involve different behavioural dynamics, all three share a common characteristic in that they all involve a perception of organizational activities as conforming to some form of construct. Suchman's typology is particularly useful for analyzing the legitimacy of businesses as it allows us to focus on a single behavioural dynamic to identify acute organizational characteristics that are contributing to legitimation success or challenges.

Of the three types of legitimacy, pragmatic legitimacy was isolated in this article because it was shown to have

Table 1. Suchman's three types of organizational legitimacy (Suchman, 1995)

\begin{tabular}{|c|c|c|c|}
\hline \multirow[b]{2}{*}{ Type of Legitimacy } & \multirow[b]{2}{*}{ Definition } & \multicolumn{2}{|c|}{ Examples } \\
\hline & & External Evaluation & Internal Evaluation \\
\hline Pragmatic & $\begin{array}{l}\text { "Pragmatic legitimacy rests on the self-interested } \\
\text { calculations of an organization's most immediate } \\
\text { audiences." }\end{array}$ & $\begin{array}{l}\text { How likely am I to } \\
\text { realize a target return } \\
\text { on investment if I } \\
\text { buy this startup's } \\
\text { product? }\end{array}$ & $\begin{array}{l}\text { How likely am I to } \\
\text { achieve my career } \\
\text { goals working at this } \\
\text { firm? }\end{array}$ \\
\hline Moral & $\begin{array}{l}\text { "Moral legitimacy reflects a positive normative } \\
\text { evaluation of an organization and its activities, and is } \\
\text { sociotropic - resting not on judgments about whether } \\
\text { a given activity benefits the evaluator but rather about } \\
\text { whether the activity is 'the right thing to do'." }\end{array}$ & $\begin{array}{l}\text { Does this firm use } \\
\text { unfair labour } \\
\text { practices? }\end{array}$ & $\begin{array}{l}\text { Do all of our } \\
\text { suppliers practice } \\
\text { adequate } \\
\text { environmental } \\
\text { stewardship? }\end{array}$ \\
\hline
\end{tabular}




\section{Resolving Legitimacy Deficits in Technology Startups through Professional Services}

Jay Payette

the most impact on an organization's ability to acquire resources (Diez-Martin et al., 2013). Additionally, Tornikoski and Newbert (2005) argue that new ventures are better served by focusing on demonstrating their capacity to deliver on a value proposition as opposed to demonstrating their existing resource endowments. Finally, considering only cognitive legitimacy, Shepherd and Zacharakis (2003) argue that cognitive legitimacy of a new venture's product is more important to the firm's success than the cognitive legitimacy of the organization and the cognitive legitimacy of the managers. The importance of product in cognitive legitimacy suggests that pragmatic legitimacy and cognitive legitimacy are linked given that an understanding of a new venture's product(s) is critical for establishing the self-serving value proposition that drives pragmatic legitimacy.

Additionally, an analysis of the collected literature suggests that, when deciding to provide resources to new ventures, the perceived ability of the new venture to deliver value to stakeholders (i.e., to execute their value proposition) carries more importance than the new venture's ability to operate within acceptable moral norms (i.e., demonstrate moral legitimacy) or to successfully articulate their purpose and operations (i.e., demonstrate cognitive legitimacy).

Finally, legitimacy can be evaluated by entities within and outside of the technology startup. Given that there are considerably more resources outside of a technology startup (e.g., customer payments, investments, grants, mentoring, partnership agreement, talent) as opposed to inside of it (e.g., employee funds, employee effort, patents, proprietary knowledge), this article focuses on how technology startups can develop pragmatic legitimacy externally as opposed to how to establish pragmatic legitimacy internally. This is not meant to discount the importance of establishing internal pragmatic legitimacy, but it does emphasize that the objective of a new venture - particularly a technology startup -is to acquire new resources, and therefore that organization would benefit from focusing primarily on the development of external pragmatic legitimacy.

\section{Developing External Pragmatic Legitimacy}

Fortunately, for technology startups, there are a number of specific actions they can take to develop all forms of legitimacy, including external pragmatic legitimacy (Suchman, 1995; Deephouse, 1996; Zimmerman \& Zeitz, 2002). According to Suchman, nearly all efforts to build legitimacy fall into three categories: i) seeking conformity to established norms through changes in the firms' behaviour, ii) seeking out an audience that consider the firm's existing behaviours as conforming to established norms, or iii) creating new audiences that consider firm behaviours as conforming to new norms. This concept of new ventures developing legitimacy via conformity has however been challenged on the basis that new ventures by definition must avoid conformity in order to survive, because existing norms represent constraints that new ventures must overcome (Rindova et al., 2009). However, although Suchman (1995) and Rindova and colleagues (2009) both provide useful theoretical frameworks, they fall short of providing prescriptive examples of specific behaviours that firms can engage in to build and expand legitimacy. Stuart, Hoang, and Hybels (1999) and Nagy, Pollack, Rutherford, and Lohrke (2012) build on the work of Suchman by suggesting that successfully developing external legitimacy depends at least partially on building social relationships between managers inside a new venture and entities outside of it. Again, although the research conducted by Stuart and, Nagy, and their colleagues make important contributions to the field of organizational legitimacy, it falls short of providing managers with specific and actionable behaviours that can directly contribute to the development of legitimacy, and none of the research above references technology startups specifically. In the next section, a specific and actionable behaviour will be proposed, which can directly contribute to the development of external pragmatic legitimacy by new ventures.

\section{Professional Services: A Solution for Technology Startups}

Unless a new venture can inherit legitimacy from internal sources, such as the founders, it must develop external pragmatic legitimacy through specific behaviours. The types of specific behaviours that a new venture can undertake may be limited, for example, by a lack of resources (Katila and Shane, 2005). A chickenand-egg scenario may result, where a technology startup lacks the legitimacy required to acquire resources and thus does not have adequate resources to invest in developing legitimacy. Given this constraint, an attractive approach to developing external pragmatic legitimacy would not demand significant financial expenditure on the part of the technology startup. In the author's experience as a management consultant, the creation of a small professional services practice is one such approach, and it need not represent considerable cost or effort (Weiss, 2009). Technology startups by definition employ scientific or technological knowledge in order to solve a problem. This internal knowledge 


\section{Resolving Legitimacy Deficits in Technology Startups through Professional Services}

Jay Payette

can not only be employed for the development of the technology startup's product(s) but it can also be "rented out" to other firms who cannot meet their demand for such skills internally. Creating a professional services practice within the existing technology startup is one mechanism that can be used to make their knowledge and experience commercially available to other firms.

Based on the definition of a professional service firm by von Nordenflycht (2010), this article defines a professional services practice as a commercial offering of the time and effort of knowledgeable professionals, without substantial capital costs. A technology startup can treat their professional services practice as an auxiliary product offering, operating alongside the technologydriven core product offering(s).

A professional services offering can contribute to the development of legitimacy to a technology startup in three ways: pragmatic verification, operational validity, and impression of viability. Pragmatic validation represents the perception that a technology startup can successfully execute a realistic value proposition with one or more entities. By successfully engaging with clients in the professional services context, technology startups create examples of their ability to create value for customers or partners. These examples help external entities to verify that the technology startup is capable of creating value, even before they have gone to market with a single product. In this way, technology startups will be able to demonstrate how the knowledge and experience within the firm have already successfully generated value outside the firm.

Operational validity represents an external entity's ability to operate their business in a way that conforms to established norms. A professional services practice provides the technology startup with the managerial experiences of operating a business before any products are ready for market. The professional services practice will require the manager of the technology startup to perform common managerial tasks, which may include marketing, billing, accounting, time management, communications, and contract management. This experience can demonstrate managerial competence to external entities, helping to alleviate a perception that the technology startup's managers are untested and potentially unreliable neophytes.

Impression of viability represents the perception by external entities that a technology startup is likely to survive, which can increase the likelihood that external entities will engage in a commercial relationship with the technology startup (Zimmerman \& Zeitz, 2002; Tornikoski \& Newbert, 2005). The presence of both revenue and ongoing customer engagements to existing customers can contribute to the perception that a technology startup is capable and committed to maintaining itself as a going concern, even if none of the revenue or customer engagements are associated with the technology startup's core products.

Thus, technology startups can create professional services practices around the knowledge and experience of individuals already within the firm, all while reducing the cost of acquiring and compensating new employees. However, by shifting from a model where the entire technology startup team dedicates all of their time on developing the technology product(s), towards a model where some of the team member's time is split between providing professional services and developing the technology product(s), the technology startup might risk delaying the go-to-market timing of its technology products. The negative impacts of such a delay must be weighed against the benefits that are generated from having some team member time successfully engaged in professional services work such as revenue, learning, the creation of social relationships, and the development of legitimacy.

\section{Conclusion}

This article has highlighted that legitimacy is important to the growth and survival of new ventures, including technology startups. When seeking to develop legitimacy, technology startups should focus on building external pragmatic legitimacy above other types of legitimacy. One method for building external pragmatic legitimacy that should be attractive to technology startups is the establishment of a professional services practice within the existing firm. A successful professional services practice contributes to the development of external pragmatic legitimacy by providing the technology startup with pragmatic validation, operational verification, and an impression of viability.

Ultimately, a professional services practice gives a technology startup the opportunity to exist as a fully functioning business before its technology products are ready to go to market. This approach shifts narratives around a technology startup away from the newness of the firm and its managers, towards the newness of a particular product offering, making the technology startup less of a startup and more of a legitimate technology company. 


\section{Resolving Legitimacy Deficits in Technology Startups through Professional Services}

Jay Payette

Although this article fills an existing gap in the literature it is only a starting point. Empirical research studying the efficacy of professional services offerings to develop pragmatic external legitimacy may provide further insights on what technology startups can do to increase their chances to not only survive, but thrive. For example, identifying case studies where technology startups both successfully and unsuccessfully attempted to use professional services to develop external legitimacy would greatly assist future research effort in this field. Additionally, research investigating the opportunity costs that developing professional services practices pose to technology startups, given limited resources, will help us understand the efficacy of this particular approach to developing external legitimacy.

\section{References}

Aldrich, H. E., \& Fiol, C. M. 1994. Fools Rush In? The Institutional Context of Industry Creation. Academy of Management Review, 19(4): 645-670.

http://dx.doi.org/10.5465/AMR.1994.9412190214

Chrisman, J. J., Bauerschmidt, A., \& Hofer, C. W. 1998. The Determinants of New Venture Performance: An Extended Model. Entrepreneurship Theory and Practice, 23(1): pp. 5-30.

Diez-Martin, F., Prado-Roman, C., \& Blanco-González, A. 2013. Beyond Legitimacy: Legitimacy Types and Organizational Success. Management Decision, 51(10): 1954-1969. http://dx.doi.org/10.1108/MD-08-2012-0561

Deephouse, D.L. 1996. Does Isomorphism Legitimate? Academy of Management Journal, 39(4): 1024-1039. http://www.jstor.org/stable/256722

Deephouse, D. L., \& Carter, S. M. 2005. An Examination of Differences between Organizational Legitimacy and Organizational Reputation. Journal of Management Studies, 42(2): 330-360. http://dx.doi.org/10.1111/j.1467-6486.2005.00499.x

Freeman, J., Carroll, G. R., \& Hannan, M. T. 1983. The Liability of Newness: Age Dependency in Organizational Death Rates. American Sociological Review, 48(5): 692-710.

http://www.jstor.org/stable/2094928

Hunt, C. S., \& Aldrich, H. E. 1996. Why Even Rodney Dangerfield Has a Homepage: Legitimizing the World Wide Web as a Medium for Commercial Endeavors. Paper presented to the annual meeting of the Academy of Management, Cincinnati, USA.

Katila, R., \& Shane, S. 2005. When Does Lack of Resources Make New Firms Innovate? Academy of Management Journal, 48(5): 814-829. http://dx.doi.org/10.5465/AMJ.2005.18803924

Nagy, B. G., Pollack, J.M., Rutherford, M. W., \& Lohrke, F. T. 2012. The Influence of Entrepreneur's Credentials and Impression Management Behaviors on Perceptions of New Venture Legitimacy. Entrepreneurship Theory and Practice, 36(5): 941-965. http://dx.doi.org/10.1111/j.1540-6520.2012.00539.x

\section{About the Author}

Jay Payette is a graduate student in the Master of Design program at Carleton University in Ottawa, Canada, and he is Managing Principal of Payette Consulting. Jay founded Payette Consulting in 2011 to help clients balance the consistent results of repeatable business processes and analytic decision making, with the fuzzy world of creativity. His research has focused on applying design-thinking principles to business model generation, strategy, and project delivery. Prior to founding Payette Consulting, Jay worked for the Canadian consulting practice of Accenture and as an independent IT Project Manager.

Reuf, M., \& Scott, W. R. 1998. A Multidimensional Model of Organizational Legitimacy: Hospital Survival in Changing Institutional Environments. Administrative Science Quarterly, 43(4): 877-904.

http://www.jstor.org/stable/2393619

Rindova, V., Barry, D., \& Ketchen, D. J. 2009. Entrepreneuring as Emancipation. Academy of Management Review, 24(3): 477-491. http://dx.doi.org/10.5465/AMR.2009.40632647

Scott, W. R., \& Meyer, J. W. 1991. The Organization of Societal Sectors. In W.W. Powell \& P.J. DiMaggio (Eds.), The New Institutionalism in Organizational Analysis: 108-140. Chicago: University of Chicago Press.

Shepherd, D. A., \& Zacharakis, A. 2003. A New Venture's Cognitive Legitimacy: An Assessment by Customers. Journal of Small Business Management, 41(2): 148-167.

http://dx.doi.org/10.1111/1540-627X.00073

Singh, J. V., Tucker, D. J., \& House, R. J. 1986. Organizational Legitimacy and the Liability of Newness. Administrative Science Quarterly, 31(2): 171-193.

http://www.jstor.org/stable/2392787

Starr, J. A., \& MacMillan, I. A. 1990. Resource Cooptation Via Social Contracting: Resource Acquisition Strategies for New Ventures. Strategic Management Journal, 11: 79-92.

Stuart, T. E., Hoang, H., \& Hybels, R. C. 1999. Interorganizational Endorsements and the Performance of Entrepreneurial Ventures. Administrative Science Quarterly, 44(2): 315-349. http://dx.doi.org/10.2307/2666998

Stinchcombe, A. L. 1965. Social Structure and Organizations. In J.G. March (Ed.), Handbook of Organizations: 142-193. Chicago: Rand McNally.

Suchman, M. C. 1995. Managing Legitimacy: Strategic and Institutional Approaches. Academy of Management Review, 20(3): 571-610. http://dx.doi.org/10.5465/AMR.1995.9508080331

Tornikoski, E. T., \& Newbert, S. L. 2005. Exploring the Determinants of Organizational Emergence: A Legitimacy Perspective. Journal of Business Venturing, 22(2): 311-335.

http://dx.doi.org/10.1016/j.jbusvent.2005.12.003 


\section{Resolving Legitimacy Deficits in Technology Startups through Professional Services}

Jay Payette

von Nordenflycht, A. 2010. What is a Professional Service Firm? Towards a Theory and Taxonomy of Knowledge Intensive Firms. Academy of Management Review, 35(1): 155-174.

Weiss, A. 2009. Getting Started in Consulting (3rd Edition). Hoboken, New Jersey: John Wiley \& Sons.

Zimmerman, M. A., \& Zeitz, G. J. 2002. Beyond Survival: Achieving New Venture Growth by Building Legitimacy. Academy of Management Review, 27(3): 414-431.

http://dx.doi.org/10.5465/AMR.2002.7389921
Citation: Payette, J. 2014. Resolving Legitimacy Deficits in Technology Startups through Professional Services

Practices. Technology Innovation Management Review, 4(6): 22-27. http://timreview.ca/article/801

Keywords: entrepreneurship, technology startups, new ventures, legitimacy, organizational legitimacy,

pragmatic legitimacy, viability, pragmatic validation, operational verification, impression of viability,

professional services (cc) BY 